\title{
HUBUNGAN TINGKAT PENGETAHUAN IBU TENTANG PERILAKU HIDUP BERSIH DAN SEHAT (PHBS) DENGAN KEJADIAN DIARE PADA BALITA DI DESA AIK AMPAT KELURAHAN DASAN GERES GERUNG LOMBOK BARAT 2019
}

\author{
Haryani $^{1}$, Sri Hardiani ${ }^{2}$, Humaediah Lestari ${ }^{3}$ \\ ${ }^{1)}$ Staf Pengajar STIKES YARSI Mataram \\ ${ }^{2,3)}$ Staf Pengajar STIKES Mataram \\ haryani444@gmail.com
}

\begin{abstract}
ABSTRAK
Penyakit diare masih menjadi salah satu masalah kesehatan masyarakat yang penting karena merupakan penyumbang ketiga angka kesakita (morbiditas) dan kematian (mortalitas) anak di berbagai negara termasuk Indonesia.

Tujuan penelitian ini adalah untuk menganalisis hubungan tingkat pengetahuan ibu tentang perilaki hidup bersih dan sehat dengan kejadian diare pada balita di Desa Aik Ampat Kelurahan Dasan Geres Gerung. Dalam pengambilan sampel peneliti menggunakan teknik non probability sampling yakni purposive sampling dengan jumlah sampel sebanyak 44 responden

Berdasarkan hasil penelitian dengan menggunakan pengisian kuesioner oleh para responden yang memiliki kriteria yang telah ditentukan untuk mengetahui hubungan tingkat pengetahuan ibu tentang perilaku hidup bersih dan sehat dengan kejadian diare pada balita di Desa Aik Ampat Kelurahan Dasan Geres Gerung. Dari 44 responden, yang menunjukkan ibu yang berpengetahuan kurang sebanyak 27 orang $(61,3 \%)$ dan dari yang berpengetahuan kurang, terdapat 26 orang ibu $(59,0 \%)$ yang mengalami kejadian diare pada balitanya. Sehingga pengetahuan ibu tentang perilaku hidup bersih dan sehat sangat perlu ditingkatkan sebagai pencegahan terjadinya diare pada balita.
\end{abstract}

Kata kunci: Tingkat pengetahuan ibu, PHBS, Diare.

\section{THE CORELATION OF MOTHER KNOWLEDGE ABOUT CLEAN AND HEALTY BEHAVIOUR WITH DIARRHEA IN TODDLERS IN AIK AMPAT VILLAGE OF DASAN GERES GERUNG WEST LOMBOK 2019}

\begin{abstract}
Diarrhea desease is one of public healt problems because it was take third place contributor to the morbidity and mortality rate of children in some countries including Indonesia.

The aim of this research is to analysis the correlation of mother knowledge about clean and healty behavior with diarrhea in toddlers in Aik Ampat village Dasan Geres Gerung. The method used in taking the samples this research is purposive sampling method the population in this research are all mother who have toddlers in Aik Ampat village Dasan Geres Gerung. The samples in this research around 44 respondents.

Based on the results of research using filling questionnaires by respondents who have predetermined criteria to determine the level of mothers about clean and healty behavior with diarrhea in toddlers in Aik ampat village Dasan geres Gerung. From 44
\end{abstract}


respondent the less knowledge mother about clean and healty behavior are 27 respondent (61,3\%) and from the less knowledge mother about clean and healty behavior there are 26 respondent (59,0\%) has experience of diarrhea. So the knowledge mother about cleand and healty behavior very important to prevent diarrhea her child.

Keywords: Knowledge mother, PHBS, Diarrhea.

\section{PENDAHULUAN}

Penyakit diare sampai saat ini masih menjadi penyebab utama dari kematian terbesar didunia. Hampir seluruh kelompok usia terserang diare khususnya paling banyak menyerang anak berusia di bawah lima tahun karena masih belum mempunyai daya tahan tubuh yang maksimal atau belum mempunyai sistem imun yang belum sepenuhnya terjaga (Sukardi \& Iskandar, 2005)

Berdasarkan etiologinya, penyakit diare dapat disebabkan oleh mikroorganisme seperti bakteri, virus, dan protozoa. Mikroorganisme penyebab diare terutama pada anak yang paling banyak ditemukan antara lain Escehercia coli entrotoksigenetik shigella, campylobacter jejuni dan cryptosporidium (Pratiwi, 2015).

Menurut data World Healt Organization (WHO) (2012) setiap tahunnya lebih dari satu milyar kasus gastroenteritis. Angka kesakitan diare pada tahun 2011 yaitu lebih 411 penderita per 1000 penduduk. Di perkirakan $82 \%$ kematian akibat gastroenteritis rotavirus terjadi pada Negara berkembang, terutama di Asia dan Afrika, dimana akses kesehatan dan status gizi masih menjadi masalah. Sedangkan data profil Indonesia menyebutkan tahun 2012 jumlah kasus diare yang ditemukan sekitar 213.435 penderita dengan jumlah kematian 1.289 , dan sebagian besar $(70-80 \%)$ terjadi pada anak - anak di bawah lima tahun. Seringkali 1-2\% penderita diare akan jatuh.

Pravalensi diare pada balita di Indonesia juga mengalami peningkatan setiap tahunnya. Dalam penelitian yang berbasis masyarakat, Riset Kesehatan Dasar (Riskesdes) yang dilaksanakan di 33 provinsi pada tahun 2007, melaporkan bahwa angka nasional pravalensi diare 9,0\%. Beberapa provinsi mempunyai pravalensi diatas angka nasional (9\%) di 14 provinsi, pravalensi tertinggi di Nanggroe Aceh Darussalam (NAD) dan terendah di Yogyakarta. Pravalensi diare berdasarkan kelompok umur pada balita (1-4 tahun) terlihat tinggi pada Riskesdes 2007 yaitu 16,7\%. Demikian pada bayi ( $<1$ tahun) yaitu 16,5\% (Kemenkes RI, 2011).

Gangguan pertumbuhan yang diakibatkan oleh diare terjadi karena asupan makanan terhenti, sementara pengeluaran zat gizi terus berjalan. Infeksi yang disebabkan oleh diare juga mempunyai kontribusi terhadap kekurangan energy, protein dan zat gizi lain. Menurunnya nafsu makan menyebabkan asupan makanan menjadi berkurang. Kebutuhan energy pada saat infeksi bisa mencapai dua kali kebutuhan normal karena meningkatnya metabolisme basal 20-60\%. Infeksi juga dapat meningkatkan kebutuhan glukosa. Infeksi berpengaruh terhadap absorbs dan katabolisme serta mempengaruhi praktek pemberian makanan selama dan sesudah sakit (Thaha dalam Kartini, 2008). Asupan makanan yang terhenti berlangsung lama akan menyebabkan berat badan bayi menurun, akibatnya bayi akan kekurangan gizi yang menghambat pertumbuhan fisik dan jaringan otak (Wijadja, 2002)

Perilaku kesehatan dapat diwujutkan dengan perilaku hidup bersih 
dan sehat harus dimulai dari unit terkecil masyarakat yaitu perilaku hidup bersih dan sehat dirumah tangga sebagai upaya untuk memberdayakan anggota rumah tangga agar tahu, mau dan mampu memperaktikkan perilaku hidup bersih dan sehat sebagai pencegahan terjadinya diare. Penerapan perilaku hidup bersih dan sehat pada balita tergantung kepada perilaku hidup bersih dan sehat ibu, karena balita masih tidak bisa melakukan segala sesuatu dengan sendiri (Departemen Kesehatan RI,2011).

Berdasarkan penelitian-penelitian yang telah dilakukan diketahui bahwa banyak faktor yang mempengaruhi kejadian diare akut pada balita. Faktor faktor tersebut diantaranya adalah faktor yang berasal dari luar dan dapat diperbaiki, sehingga dengan memperbaiki faktor resiko tersebut diharapkan dapat menekan angka kesakitan dan kematian diare pada balita.

Tabel Data kunjungan diare di Puskesmas Pembantu Aik Ampat bulan Januari-Oktober tahun 2017.

\begin{tabular}{|c|l|l|}
\hline No & \multicolumn{1}{|c|}{ Bulan } & \multicolumn{1}{|c|}{ Jumlah Kunjungan } \\
\hline 1 & Januari & 56 kunjungan \\
\hline 2 & Februari & 48 kunjungan \\
\hline 3 & Maret & 50 kunjungan \\
\hline 4 & April & 53 kunjungan \\
\hline 5 & Mei & 49 kunjungan \\
\hline 6 & Juni & 52 kunjungan \\
\hline 7 & Juli & 48 kunjungan \\
\hline 8 & Agustus & 45 kunjungan \\
\hline 9 & September & 54 kunjungan \\
\hline 10 & Oktober & 51 kunjungan \\
\hline \multicolumn{2}{|c|}{ Total } & 506 kunjungan \\
\hline
\end{tabular}

Dari data kunjungan di atas, didapatkan bahwa jumlah kunjungan diare di Puskesmas Pembantu Aik Ampat bulan Januari-Oktober tahun 2018, terdapat 1-2 pasien diare perhari. Ini berarti bahwa di Puskesmas Pembantu Aik Ampat yang membawahi satu kelurahan (Dasan Geres) setiap hari selalu ada pasien yang datang dengan penyakit dare. Dan dengan beberapa faktor penyebab terjadinya diare yang tertera diatas. Oleh karena itu penulis meneiti hubungan tingkat pengetahuan ibu tentang perilaku hidup bersih dan sehat dengan kejadian diare pada balita di Desa Aik Ampat Kelurahan Dasan Geres Gerung.

\section{BAHAN DAN METODE}

Jenis Penelitian

\begin{tabular}{|c|c|c|c|c|c|c|}
\hline & & \multicolumn{2}{|c|}{ Kejadian diare } & & \multirow[b]{2}{*}{$\mathrm{R}$} & \multirow[b]{2}{*}{ P-value } \\
\hline No & Pengetahuan & $\begin{array}{l}\text { Ada } \\
(\%)\end{array}$ & $\begin{array}{c}\text { Tidak } \\
(\%)\end{array}$ & $\begin{array}{c}\text { Jumlah } \\
(\%)\end{array}$ & & \\
\hline 1 & Baik & $1(2,27)$ & $6(13,6)$ & $7(15,9)$ & \multirow{4}{*}{-.753} & \multirow{4}{*}{.001} \\
\hline 2 & Cukup & $2(4,54)$ & $8(18,1)$ & $10(22,7)$ & & \\
\hline 3 & Kurang & $26(59,0)$ & $1(2,27)$ & $27(61,3)$ & & \\
\hline & Total & 29 & 15 & 44 & & \\
\hline
\end{tabular}

Penelitian yang digunakan adalah descriptive corelational yaitu penelitian yang bertujuan untuk mengungkapkan hubungan korelasi antar variabel dalam penelitian (Nursalam, 2003). Jenis penelitian yang digunakan adalah kuantitatif dengan menggunakan desain pendekatan Cross Sectional yaitu suatu penelitian untuk mempelajari hubungan antara variabel bebas dan variabel terikat dengan melakukan pengukuran sesaat, dengan cara mengambil sampel dari suatu populasi tertentu dengan menggunakan kuesioner sebagai alat pengumpul data pokok (Notoatmojo, 2002). Dalam penelitian ini menggambarkan korelasi hubungan tingkat pengetahuan ibu tentang perilaku hidup bersih dan sehat (PHBS) dengan kejadian diare pada balita di Desa Aik Ampat Kelurahan Dasan Geres Gerung.

\section{HASIL DAN PEMBAHASAN}

Hasil uji dua hubungan yang diteliti dalam penelitian ini dengan menggunakan uji rank correlation atau sering juga disebut korelasi spearman 
rank dapat dilihat pada tabel sebagai berikut:

Tabel Hubungan tingkat pengetahuan ibu tentang perilaku hidup bersih dan sehat (PBHS) dengan kejadian diare pada balita.

Sumber: Data Primer 2019

Berdasarkan tabel di atas hasil analisis Hubungan tingkat pengetahuan ibu tentang perilaku hidup bersih dan sehat (PHBS) dengan kejadian diare pada balita diperoleh ada sebanyak $1(2,27 \%)$ responden yang berpengetahuan baik yang pernah mengalami kejadian diare pada balitanya, ada $6 \quad(13,6 \%)$ orang responden yang berpengetahuan baik, belum pernah mengalami kejadian diare pada balitanya. Selanjutnya ada responden yang berpengetahuan cukup 2 orang $(4,54 \%)$ responden yang pernah mengalami kejadian diare pada balitanya, dan ada responden yang berpengetahuan cukup 8 orang $(18,1 \%)$ yang tidak atau belum pernah mengalami kejadian diare pada balitanya. Selanjutnya ada responden yang berpengetahuan kurang, ada 26 orang $(59,0 \%)$ yang pernah mengalami kejadian diare pada balitanya, dan ada responden berpengetahuan kurang 1 orang responden $(2,27 \%)$ yang tidak atau belum pernah mengalami kejadian diare pada balitanya.Hasil uji korelasi spearman rank di dapatkan p-value = 0,000 jadi $p$-value $<0,001$ sehingga $\mathrm{Ha}$ diterima dan Ho ditolak, artinya ada hubungan tingkat pengetahuan ibu tentang perilaku hidup bersih dan sehat dengan kejadian diare pada balita. Nilai korelasi spearman rank sebesar $-0,753$ menunjukkan bahwa arah korelasi negatif dengan kekuatan korelasi kuat.

\section{PEMBAHASAN}

Berdasarkan penelitian yang dilakukan di Desa Aik Ampat Kelurahan Dasan Geres Gerung dengan judul
"Hubungan Tingkat Pengetahuan Ibu Tentang Perilaku Hidup Bersih Dan Sehat (PHBS) Dengan Kejadian Diare Pada Balita Di Desa Aik Ampat Kelurahan Dasan Geres Gerung" maka akan diuraikan berdasarkan sub variabel dan tujuan dari penelitian ini adalah untuk mengetahui hubungan tingkat pengetahuan ibu tentang perilaku hidup bersih dan sehat (PHBS) dengan kejadian diare pada balita.

Berdasarkan data menunjukkan bahwa dari 44 responden kelompok umur umur 20-28 tahun sebanyak 7 orang $(15,9 \%)$, selanjutnya kelompok umur 29-35 tahun sebanyak 25 orang $(56,8 \%)$ dan kelompok umur 36-42 tahun sebanyak 12 orang $(27,3 \%)$. Semakin bertambahnya usia seseorang maka akan semakin mampu menunjukkan kematangan jiwa, mengendalikan emosi, dan tampil menjalankan tugas sebagai seorang ibu yang memiliki putra/putri yang masih balita (Atikah, 2010). Bertambahnya umur ibu dapat menjadiakan pengalaman dan pengetahuan responden tentang diare pada balita meningkat. Menurut Hendra (2008), semakin bertambah umur seseorang maka proses-proses perkembangan mentalnya membaik serta berpengaruh pada pengetahuan yang diperolehnya. Biasanya umur memiliki ketergantungan tinggi dengan lingkungan tetapi jika kurang terpapar dengan pendidikan, tentunya akan terbawa arus lingkungan yang tidak sesuai dan berbuat sesuai dengan yang mereka rasakan (ahira, 2008).

Berdasarkan hasil menunjukkan bahwa dari 44 responden berdasarkan pekerjaan adalah sebagian besar responden sebagai IRT yaitu sebanyak 18 orang responden $(40,9 \%)$. Dan paling sedikit responden yang bekerja sebagai Guru yaitu sebanyak 3 orang responden $(6,8 \%)$. Pendapat Wawan (2010) yang menyatakan bahwa pengetahuan dan sikap seseorang dipengaruhi oleh banyak 
faktor diantaranya umur, pendidikan dam pekerjaan.Pendidikan dapat menambah wawasan dan pengetahuan.

Seseorang yang mempunyai pendidikan lebih tinggi akan mempunyai pengethuan lebih luas dibandingkan dengan tingkat pendidikan yang lebih rendah. Pengetahuan cukup itu sendiri dipengaruhi oleh faktor pendidikan formal. Pengetahuan sangat erat hubungannya dengan pendidikan, dimana diharapkan bahwa dengan pendidikan yang tinggi maka orang tersebut akan semakin luas pula pengetahuannya. Akan tetapi perlu ditekankan, bukan berarti seseorang yang berpendidikan rendah mutlak berpengetahuan rendah pula. Hal ini mengingat bahwa peningkatan pengetahuan tidak mutlak diperoleh dari pendidikan formal saja, akan tetapi dapat diperoleh melalui pendidikan non formal (Notoatmodjo, 2012).

Pendidikan mempengaruhi kesempatan untuk memperoleh informasi, dimana responden dengan pendidikan yang rendah cenderung kurang mampu untuk mengadopsi halhal baru.Pengetahuan merupakan hasil dari tahu.Dan ini diperoleh setelah seseorang melakukan pengindraan terhadap suatu objek (Notoatmodjo, 2007).

Berdasarkan hasil distribusi Tabel menunjukkan bahwa 44 responden yang berpengetahuan baik sebanyak 7 orang $(15,9 \%)$, selanjutnya responden yang berpengetahuan cukup sebanyak 10 orang $(22,7 \%)$. Dan responden yang berpengetahuan kurang sebanyak 27 orang (61,4\%). Menurut Hurlock (1998) dalam Fajriyah (2009). Pengalaman dalam bekerja memberikan pengetahuan dan keterampilan ibu serta pengalaman belajar selama bekerja akan dapat mengembangkan kemampuan mengambil keputusan yang merupakan manifestasi dari keterpaduan menalar secara ilmiah dan dari masalah nyata dalam bidang kerjanya (Hendra, 2008).

Salah satu yang mempengaruhi pengatahuan adalah faktor lingkungan.Pekerjaan berpengaruh terhadap tingkat pengetahuan yang dimiliki seseorang. Seseorang yang bekerja dilingkungan yang didukung akses informasi akan banyak mendapat pengetahuan dibandingkan dengan orang yang bekerja di tempat-tempat yang tertutup dari akses informasi (Azwar, 2007).

Dari hasil distribusi Tabel 5.4 menunjukkan bahwa dari 44 responden, ada $29(65,9 \%)$ orang responden yang balitanya pernah mengalami kejadian diare. Selanjutnya ada 15 orang $(34,0 \%)$ responden yang belum pernah mengalami kejadian diare pada balitanya.

Faktor-faktor yang dapat mempengaruhi kurangnya pengetahuan ibu tentang diare pada balita dalam lingkungan antara lain kurangnya informasi dari tenaga kesehatan kepada ibu, kurang jelasnya informasi yang disampaikan oleh tenaga kesehatan kepada ibu, kurangnya kemampuan dari ibu untuk memahami informasi yang diberikan (Notoatmodjo, 2012).

Selain itu pengetahuan juga dapat diperoleh dari pegalaman, Suliha (2012) mengemukakan bahwa sesuatu yang dialami seseorang tentang masalah kesehatan yang dihadapi akan menambah pengetahuan tentang msalah kesehatan itu. Pandangan lain ditemukan oleh Heransyah (2007), yang menyatakan bahwa pengetahuan dapat juga didapat melalui pengalaman pribadi manusia yang terjadi berulangkali. Jika seseorang memiliki pengalaman yang lebih, maka akan menghasilkan pengetahuan yang lebih.

Salah satu contoh menerapkan perilaku hidup dan bersih sebagai pencegahan diare ialah mencuci tangan dengan air bersih dan sabun terutama 
sangat penting saat setelah buang air besar dan menceboki balita, karena dapat menghambat penularan kuman yang disebabkan oleh diare.Mencuci tangan dengan air bersih dan sabun dapat membersihkan kotoran dan membunuh kuman.Air yang tidak bersih banyak mengandung kuman dan bakteri (Departemen Kesehatan RI, 2007). Kebiasaan tidak mencuci tangan mempunyai resiko 1,88 kali lebih besar akan menderita diare dibandingkan dengan yang mencuci tangan. Mencuci tangan dapat menurunkan resiko terkena diare sebesar $47 \%$ (Departemen Kesehatan RI dalam Muhajirin, 2007).

Hasil analisis Hubungan tingkat pengetahuan ibu tentang perilaku hidup bersih dan sehat (PHBS) dengan kejadian diare pada balita diperoleh ada sebanyak $1(2,27 \%)$ responden yang berpengetahuan baik yang pernah mengalami kejadian diare pada balitanya, ada $6(13,6 \%)$ orang responden yang berpengetahuan baik, belum pernah mengalami kejadian diare pada balitanya. Selanjutnya ada responden yang berpengetahuan cukup 2 orang $(4,54 \%)$ responden yang pernah mengalami kejadian diare pada balitanya, dan ada responden yang berpengetahuan cukup 8 orang $(18,1 \%)$ yang tidak atau belum pernah mengalami kejadian diare pada balitanya. Selanjutnya ada responden yang berpengetahuan kurang, ada 26 orang $(59,0 \%)$ yang pernah mengalami kejadian diare pada balitanya, dan ada responden berpengetahuan kurang 1 orang responden $(2,27 \%)$ yang tidak atau belum pernah mengalami kejadian diare pada balitanya.Hasil uji korelasi spearman rank di dapatkan $p$-value $=$ 0,000 jadi $p$-value $<0,001$ sehingga $\mathrm{Ha}$ diterima dan Ho ditolak, artinya ada hubungan tingkat pengetahuan ibu tentang perilaku hidup bersih dan sehat dengan kejadian diare pada balita. Nilai korelasi spearman rank sebesar $-0,753$ menunjukkan bahwa arah korelasi negatif dengan kekuatan korelasi kuat.

Kekuatan korelasi pada hasil penelitian ini adalah $-0,753$ yang menunjukkan ada hubungan yang kuat antara tingkat pengetahuan ibu tentang perilaku hidup bersih dan sehat (PHBS) dengan kejadian diare pada balita di Desa Aik Ampat Kelurahan Dsan Geres Gerung.Hasil penelitian menunjukkan bahwa tidak semua ibu yang memiliki balita yang tidak diare memiliki perilaku hidup bersih dan sehat (PHBS) yang baik. Hal ini selaras dengan teori yang dikemukakan oleh Santo et al (1999) bahwa terdapat beberapa faktor yang dapat menyebabkan diare, yaitu faktor dari dalam dan faktor luar.Faktor luar merupakan faktor diluar tubuh yang menyebabkan resiko terjadinya diare.Dari dalam tubuh seseorang. Faktor luar terdiri dari pemakaian air yang kotor, kurangnya sarana kebersihan, lingkungan yang jelek, penyimpanan makanan yang tidak semestinya, penghentian Asi terlalu cepat, pemberian susu formula, dan penerapan perilaku hidup bersih dan sehat yang lain. Sedangikan faktor dalam terdiri dari gizi kurang, daya tahan menurun, berkurangnya keasaman lambung, berkurangnya motalitas usus, dan faktor genetik.

Pada ibu yang memiliki perilaku hidup bersih dan sehat (PHBS) yang Kurang terdapat lebih banyak balitanya yang terkena diare meskipun ada juga ibu yang berpengetahuan perilaku hidup bersih dan sehat yang kurang belum pernah mengalami kejadian diare pada balitanya. Hal ini menunjukkan bahwa tingkat pengetahuan ibu tentang perilaku hidup bersih dan sehat (PHBS) berhubungan dengan kejadian diare pada balita, karena itu dibutuhkannya tingkat pengetahuan yang baik untuk para ibu yang memiliki balita tentang perilaku hidup bersih dan sehat sebagai penerapan perilaku tersebut dapat 
menegtahui pencegahan maupun penanganan diare pada balitanya.

\section{SIMPULAN}

Berdasarkan analisis dan pembahasan hasil penelitian maka ditarik kesimpilan. Ada Hubungan Tingkat Pengetahuan Ibu Tentang Perilaku Hidup Bersih dan Sehat dengan Kejadian Diare Pada Balita Di Desa Aik Ampat Kelurahan Dasan Geres Gerung Lombok Barat

\section{DAFTAR PUSTAKA}

Anne, Ahira . (2008).Epidemiologi Diare : Karena Lingkungan yang Kotor. Arikunto, Suharsimi (2006). Prosedur Penelitian Suatu Pendekatan Praktik, Jakarta, Rineka Cipta.

Atikah Proverawati, MPH. 2010. Menopause dan Sindrom Pre Menopause. Yogyakarta: Muha Medika

Azwar, Saifuddin. 2007.Metode Penelitian. Yogyskarta: Pustaka Pelajar.

Departemen Kesehatan RI. 2011 . Diare Akut. Buku Ajar Diare. Jakarta: Depkes RI.

Departemen Kesehatan RI. 2011. Rumah Tangga Sehat Dengan Perilaku Hidup Bersih Dan Sehat. Jakarta: Pusat Promosi Kesehatan Departemen Kesehatan RI.

Depkes, R. I. 2015 Pedoman Pemberantasan Penyakit Diare. Jakarta: Ditjen Ppm Dan PI.

Depkes R. I. 2016 Direktorat Jendral Binkesmas Direktorat Bina Gizi Masyarakat. Petunjuk Pelaksanaan Peningkatan Asi Eksklusif, Jakarta.

Depkes, R. I. 2010 Pedoman Pemberantasan Penyakit Diare. Jakarta: Ditjen Ppm Dan Pl.

Depkes, R. I. Buku Pedoman Pelaksanaan Program P2 Diare. Jakarta: Ditjen Ppm No. 2. JuliDesember 2005: 163-193;2000

Fernitaoktaviyani. 2010. Epidemiologi Penyakit Diare di Wilayah Kerja Puskesmas Kendar.

Hendra, AW, 2008, Faktor-Faktor Yang Mempengaruhi Pengetahuan, Jakarta : Pustaka Sinar. Harapan

Hurlock, E. B. 1998. Psikologisb Perkembangan (Suatu Pendekatan Sepanjang Rentang Kehidupan). Jakarta: Erlangga

Ngastiyah. 2010 Asuhan Keperawatan Penyakit Dalam. Edisi II. Jakarta: EGC. 
Notoadmodjo, S. 2010 Ilmu Perilaku Kesehatan. Jakarta: Rineka Cipta.

Notoadmodjo, S. 2007 Konsep Perilaku Dan Perilaku Kesehatan. Dalam:Notoatmojdjo, S.Promosi Kesehatan Dan Ilmu Perilaku. Jakarta:Rineka Cipta

Notoatmodjo, S. 2012 Metodologi Penelitian Kesehatan, edisi revisi . Jakarta: Rineka Cipta.

Notoatmojdjo, S. 2015 Promosi Kesehatan Dan Ilmu Perilaku edisi revisi Jakarta:Rineka Cipta;

Nursalam (2003). Konsep dan Penerapan Metodologi Penelitian Ilmu Keperawatan, Jakarta, Salemba Medika.

Soegijanto, S.,2002. Ilmu Penyakit Anak: Diagnosa dan Penatalaksanaan, Edisi Pertama, Salemba Medika, Jakarta.

Soegiyanto, 2012. Ilmu Penyakit Anak. Jakarta: Penerbit Salemba Medika.

Soebagyo, B. Diare Akut Pada Anak. Surakarta: Universitas Sebelas Maret Press; 2008

Suharyono. (2008). Diare Akut. Jakarta; Rineka Cipta

Uhu Suliha dkk. 2012. Pendidikan Kesehatan Dalam Keperawatan. Jakarta:EGC.

Wawan dan Dewi, 2010, Teori dan Pengkuran Pengetahuan, Sikap dan Perilaku Manusia, Yogyakarta : Nuha Medika

World Healt Organization (WHO). 2012. Global Water Supply And Sanitation Assesment. World Healt Organization. 